STUDI KASUS DEMO BERUJUNG KERUSUHAN 21-22 MEI 2019 PASCA PENGUMUMAN HASIL PILPRES 2019 DITINJAU DARI TEORI TINDAKAN MANUSIA, TATANAN MORAL SUBJEKTIF, DAN TATANAN MORAL OBJEKTIF

Dosen Pembimbing Dr. Agustinus W. Dewantara, S.S., M.Hum

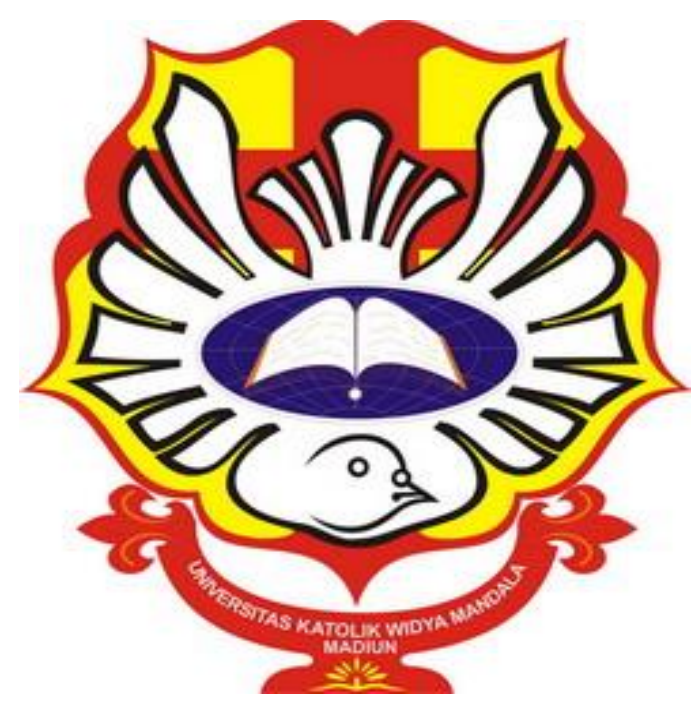

Disusun Oleh :

LIA SAFITRI

(3803019011)

FAKULTAS EKONOMI DAN BISNIS

PROGRAM STUDI AKUNTANSI

UNIVERITAS KATOLIK WIDYA MANDALA SURABAYA

KAMPUS MADIUN

Jl. Manggis 15-17 Madiun 632131 Telp. 0351-453167

TAHUN 2019 


\title{
STUDI KASUS DEMO BERUJUNG KERUSUHAN 21-22 MEI 2019 PASCA PENGUMUMAN HASIL PILPRES 2019 DITINJAU DARI TEORI TINDAKAN MANUSIA, TATANAN MORAL SUBJEKTIF, DAN TATANAN MORAL OBJEKTIF
}

\author{
Oleh : \\ Lia Safitri (3803019011) \\ Program Studi Akuntansi Fakultas Ekonomi dan Bisnis, \\ Universitas Katolik Widya Mandala Surabaya Kampus Madiun
}

\begin{abstract}
ABSTRAK
Demo berujung pada kerusuhan tanggal 21-22 Mei 2019 menjadi salah satu peristiwa yang mencoreng demokrasi negara Indonesia. Dimana tindakantindakan massa dalam peristiwa tersebut secara hukum melanggar peraturan negara yang merupakan tatanan moral objektif. Berdasarkan penyelidikan kasus kerusuhan oleh pihak polisi, ada beberapa poin dalam kasus tersebut yang dapat disorot dengan teori tatanan moral subjektif dimana hati nurani bertindak sebagai instansi pengawas dan juga berdasarkan teori tindakan manusia. Dari poin-poin yang disoroti tersebut, menunjukkan keprihatinan bangsa di dalam pelaksanaan kehidupan bernegara salah satunya demo. Negara kita menjamin kemerdekaan penyampaian pendapat di muka umum bagi warga negaranya, seharusnya kesempatan tersebut digunakan sebaik-baiknya.
\end{abstract}

Keywords : Kerusuhan, tindakan manusia, tatanan moral subjektif dan objektif 


\section{A. PENDAHULUAN}

Tahun 2019 adalah sebutan tahun panas dan tahun politik bagi Indonesia. Dapat dikatakan seperti itu, karena pada tahun tersebut negara menyelenggarakan pesta demokrasi yakni Pemilu serentak, pemilihan anggota DPR RI, DPD, dan DPRD Provinsi, DPRD kabupaten/kota se-Indonesia periode 2019-2024, dilaksanakan bersamaan dengan Pemilihan Presiden dan Wakil Presiden RI periode 2019-2024, yang diselenggarakan tanggal 17 April 2019. Indonesia telah sukses menyelenggarakan pemilu besar tersebut, proses pemilihan berjalan dengan lancar, tertib, hingga ke pelosok negeri. Indonesia menuai banyak pujian dari beberapa negara terkait keberhasilan tersebut.

Pada Selasa dini hari tanggal 21 Mei 2019, KPU mengumumkan hasil pemilihan umum presiden dan wakil presiden 2019 dengan terpilihnya pasangan capres dan cawapres nomor urut 01, yakni Jokowi-Ma'ruf dengan perolehan suara 85.607.362 atau 55,50 \% dari total suara sah nasional. Sementara, pasangan capres-cawapres nomor urut 02 Prabowo-Sandi, memperoleh suara 68.650.239 atau $44,50 \%$ dari total suara sah nasional. Sedangkan, total keseluruhan jumlah suara sah nasional yakni 154.257.601 suara.

Berdasarkan hasil keputusan KPU tersebut, banyak masyarakat pendukung pasangan capres-cawapres Prabowo-Sandi yang tidak terima, sehingga banyak warga yang melakukan demo terkait penolakan hasil keputusan KPU dan dugaan praktik kecurangan banyak terjadi di Pemilu Presiden dan Wakil Presiden 2019.

Di Indonesia, demo memang diperbolehkan, namun dalam kasus demo penolakan tersebut, sangat memprihatinkan dan banyak menyimpang dari berbagai aturan. Banyak penjarahan terjadi, tindakan anarkis dengan pelemparan batu dan petasan kepada aparat yang berjaga, hingga ke pembunuhan.

Inilah salah satu bentuk dari keprihatinan bangsa yang mencoreng demokrasi di Indonesia, penyalahgunaan hak menyampaikan pendapat yang telah diberikan dengan sangat berambisi demi tujuan golongan tertentu saja, tanpa memperdulikan dampak dan akibat terhadap sesamanya, lingkungannya, dan yang paling penting keutuhan Negara Kesatuan Republik Indonesia. 


\section{B. KASUS DEMO BERUJUNG KERUSUHAN 21-22 MEI 2019 PASCA PENGUMUMAN HASIL PILPRES 2019}

\section{KRONOLOGI DEMO 21-22 MEI 2019 YANG BERUJUNG KERUSUHAN}

Unjuk rasa atau demo di dalam kehidupan bernegara terutama negara demokrasi seperti Indonesia memang diperbolehkan, demikian pula yang terjadi pasca pengumuman hasil Pilpres 2019. Demo yang terjadi tanggal 21-22 Mei 2019 merupakan penolakan warga masyarakat pendukung pasangan caprescawapres Prabowo-Sandi terhadap keputusan KPU terkait perhitungan suara Pemilihan umum Presiden dan Wakil Presiden RI tahun 2019, yang menghasilkan keputusan terpilihnya Jokowi-Ma'ruf sebagai Presiden dan Wakil Presiden RI terpilih periode 2019-2024. Para demonstran, beranggapan bahwa terdapat banyak praktik kecurangan oleh penyelenggara dalam pelaksanaan Pemilihan Presiden dan Wakil Presiden 2019.

Demo berlangsung mulai dari Selasa siang tanggal 21 Mei 2019 hingga Kamis dini hari tanggal 23 Mei 2019. Awalnya demo penolakan tersebut berjalan dengan lancar dan tertib di depan kantor Bawaslu, yang beralamat di Jl. M.H. Thamrin, Gondangdia, Menteng, Jakarta Pusat, pada Selasa, 21 Mei 2019 mulai siang hingga petang. Polisi memberikan toleransi kepada para demonstran untuk pelaksanaan demo diizinkan hingga pukul $21.00 \mathrm{WIB}$, padahal berdasarkan aturan demonstrasi, seharusnya massa demonstran harus membubarkan diri pada pukul 18:00 WIB. Pada pukul 21.00 WIB, massa pun membubarkan diri dengan tertib, namun pada pukul 23.00 WIB, tiba-tiba datang massa misterius dan melakukan tindakan anarkis serta provokasi yang membuat situasi semakin runyam. Massa bertindak brutal dengan melempar batu, bom Molotov bahkan petasan ukuran besar kepada petugas. Aparat yang berjaga tetap berusaha untuk menghimbau massa untuk membubarkan diri dengan damai dan tertib.

Pada hari Rabu, 22 Mei 2019, pukul 03.00 WIB, kerusuhan terjadi lagi di tempat yang lain, ada sekelompok 200 massa yang berbeda dengan sebelumnya, berkumpul di Jl. K.S. Tubu, Jakarta Barat. Massa tersebut kemudian menuju ke 
arah asrama Mabes Polri di Petamburan dan berbuat kerusuhan di asrama Brimob, mereka beritindak anarkis dengan melempar batu, botol, bom molotov, juga petasan. Petugas piket asrama sudah berusaha menghalau dengan gas air mata, namun justru massa semakin brutal dengan merusak dan membakar belasan kendaraan pribadi hingga dinas. Jumlah mobil yang rusak 11 unit kerusakan kaca depan, 14 unit terbakar, yakni diantaranya truk Pengendali Massa satpol PP, mobil dalmas dan 11 unit mobil umum.

Kerusuhan berlanjut dan terjadi di Jl. Jati Baru Raya, Tanah Abang pada pukul 09.00 WIB. Bentrokan massa dengan aparat tak terelakkan, massa melempari polisi dengan berbagai barang. Polisi berusaha membubarkan kerusuhan dengan menggunakan gas air mata.

Siangnya, aksi rusuh juga terjadi di Jalan Slipi 1, Palmerah hingga ke arah Flyover Slipi pada pukul 11.20 WIB. Sama halnya dengan demo di tempat lain, massa juga melempari petugas yang berjaga.

Rabu petang, dimulai saat pukul 18:30 WIB, demonstran berbuat kerusuhan di depan kantor Bawaslu, berawal dari massa yang mengabaikam himbauan polisi untuk segera bubar dengan damai dan tertib. Namun massa justru berbuat anarkis dengan terus-menerus melempari aparat dengan botol, petasan, bahkan bom molotov dan berbagai barang. Polisi tetap berusaha mengamankan situasi dengan cara berorasi dan bertahan berjaga di depan kantor Bawaslu. Bahkan dengan adanya kerusuhan yang terjadi di berbagai tempat vital di Ibu Kota, pihak aparat kepolisian memperketat penjagaan di Istana Negara hingga Kamis dini hari. 


\section{AKIBAT DAN TEMUAN KERUSUHAN 21-22 MEI 2019}

\section{a. PENJARAHAN DAN KERUSAKAN}

Para demonstran 21-22 Mei 2019, ternyata tak hanya melakukan aksi unjuk rasa biasa, namun mereka juga melakukan penjarahan warung-warung di kawasan Jakarta Pusat. Uang pedagang dan semua barang dagangan seperti mie instan, rokok, roti dan lain sebagainya, ludes dijarah dan tak ada yang tersisa. Tak hanya itu, para demonstran juga merusak warung, memecahkan kacanya.

Tak hanya penjarahan, massa juga melakukan perusakan di fasilitasfasilitas penting dan juga mengganggu ketertiban umum, seperti mesin atm yang dihancurkan, pos polisi yang dibakar, motor warga yang dirusak dan dibakar. Begitu pula pagar Bawaslu, yang dirusak dan dibakar oleh para perusuh.

\section{b. KORBAN TEWAS DAN LUKA-LUKA}

Tak dipungkiri lagi bahwa demo yang dilakukan dengan anarkis dan brutal yang berujung pada kerusuhan, akan menimbulkan korban. Gubenur DKI Jakarta, Anies Baswedan mengatakan bahwa hingga hari Rabu 22 Mei 2019 per pukul 09.00 WIB, berdasarkan data yang diterimanya dari Dinas Kesehatan DKI Jakarta, tercatat ada sekitar 200 orang luka-luka. Para korban luka-luka dirujuk dan dirawat di beberapa rumah sakit di daerah Jakarta.

Selain korban luka, kerusuhan juga menimbulkan korban jiwa. Saat konferensi pers di Media Center Kemenko Polhukam Jakarta Pusat, Selasa, 11 Juni 2019, Kepala Divisi Humas Polri Inspektur Jenderal M. Iqbal menyebutkan bahwa jumlah korban meninggal dunia akibat kerusuhan 21-22 Mei 2019 sebanyak 9 orang. Kesembilan korban tewas tersebut terduga perusuh.

Direktur Reskrimum Polda Metro Jaya, Kombes Suyudi Ario Seto mengatakan bahwa berdasarkan hasil penyelidikan polisi, 4 dari sembilan korban tewas tersebut mengalami luka tembak. Otopsi dan visum oleh pihak kepolisian hanya dilakukan pada 2 korban saja, karena korban lainnya tidak mendapat izin dari pihak keluarga. Kedua korban tewas tersebut diduga sengaja ditembak oleh orang yang tidak dikenal. Hal itu dikarenakan hasil penyelidikan polisi dari uji 
balistik terhadap proyektil dalam tubuh kedua korban, menunjukkan arah proyektil berlawanan dengan posisi aparat yang berjaga di lokasi ditemukannya korban. Selain itu, Menteri Koordinator bidang Politik, Hukum dan Keamanan, Wiranto mengatakan bahwa tidak mungkin petugas polisi sebagai pelaku penembakan, aparat tidak dibekali peluru tajam saat bertugas mengamankan massa. Ada saksi yang mengatakan bahwa ada yang mengarahkan pistol hitam ke arah kerumunan massa saat demo. Polisi pun terus berusaha menyelidiki dan melakukan olah TKP serta mencari sumber-sumber dari saksi, terkait kasus ini.

\section{c. MASSA TERORGANISIR}

Demo pada tanggal 21-22 Mei 2019 yang berujung pada kerusuhan, ternyata terdapat hal yang mengganjal. Aksi rusuh yang terjadi pada Selasa malam, 21 Mei 2019 di depan Gedung Bawaslu dan Rabu dini hari, 22 Mei 2019 di Petamburan yang menyerang asrama Brimob dan Tanah Abang, Jakarta Pusat. Dalam konferensi pers Rabu (22/05/2019), Kepala Divisi Humas Polri Irjen M. Iqbal mengatakan bahwa peristiwa kerusuhan Rabu dini hari tersebut bukan massa spontan, melainkan sudah di design atau di setting. Teridentifikasi dari pergerakan kelompok massa yang rapi dan terencana. Massa rusuh tersebut berbeda dengan massa yang melakukan demo dengan aksi damai ketika siang hari, mereka telah membubarkan diri pada pukul 21:00 WIB.

Dari kejadian tersebut, Menkopolhukam Wiranto mengatakan bahwa sseperti sudah ada sebuah skenario penataan yang dibuat untuk mengerahkan massa agar mereka bertindak anarkis dan brutal. Hal tersebut terlihat dari buktibukti yang diperoleh oleh pihak polisi berupa amplop dengan isi uang sekitar Rp 6 juta yang berasal dari provokator-provokator yang ditangkap. Mereka juga mengaku dibayar untuk melakukan aksinya. Hasil dari pemeriksaan polisi, ternyata mayoritas dari provokator ini adalah pemuda-pemuda yang dibayar. Selain pemuda, aksi massa yang anarkis tersebut juga dilakukan oleh sekelompok orang bertato atau preman yang dibayar untuk berbuat brutal, menyerang aparat keamanan termasuk asrama kepolisian. 
Dugaan massa yang terorganisir tersebut, semakin diperkuat dari hasil rekaman CCTV yang terpasang di dekat salah satu gedung di Jl. M.H. Thamrin., Jakarta. Rabu 22 Mei 2019 dini hari, lebih tepatnya pukul 02:00 WIB, ada pergerakan massa di jalur bus Transjakarta. Dalam rekaman CCTV tersebut, menunjukkan sekelompok pemuda yang turun dari ambulans dan kemudian ada amplop yang dibagikan, pemuda-pemuda lain di dekat lokasi juga mendekat dan menerima amplop. Setelah menerima amplop, mereka langsung membubarkan diri dan berlari menuju kawasan demo. 


\section{LANDASAN TEORI}

\section{TINDAKAN MANUSIA}

Bertindak merupakan salah satu ciri dari makhluk hidup. Dalam bertindak, manusia seharusnya tidak hanya berkaitan dengan eksistensinya sebagai makhluk hidup, namun juga untuk menunjukkan eksistensi manusia secara mendalam. Tindakan manusia merupakan pencetusan dirinya, sepintas secara konkret direpresentasi dan ditentukan oleh tindakannya. Maurice Blondel mengatakan bahwa tindakan manusia merupakan representasi dirinya yang paling umum dan juga merupakan representasi dirinya yang paling lengkap.(Dewantara, 2017: 9)

Ada dua distingsi mengenai tindakan manusia, yakni Actus Hominis dan Actus Humanus.

a. Actus hominis, berasal dara bahasa Latin, actus yang berarti tindakan, homo yang berarti manusia, dan is yang berarti pemilik, sehingga actus hominis berarti tindakan yang dimiliki manusia, contohnya makan, minum, berjalan, berlari. Dalam hal ini, manusia tidak menyertakan peran rasionya dalam bertindak. Bertindak hanya berdasarkan insting, refleks dan nampak hanya menunjukkan bertindak sebagai salah satu dari ciri makhluk hidup, sehingga dalam konteks ini, tindakan manusia yang demikian terlihat sama halnya dengan binatang, binatang juga melakukan tindakan makan, tidur, minum, berlari.

b. Actus humanus, berasal dari bahasa Latin, asal kata dari actus yang berarti tindakan, homo yang berarti manusia, dan us yang berarti sifat. Sehingga actus humanus berarti tindakan manusia yang manusiawi. Yang termasuk dalam golongan ini adalah semua tindakan manusia yang menyertakan akal budi, yaitu tindakan yang dilakukan dengan tahu, mau, bebas, artinya mempunyai pengetahuan, kemauan, dan kebebasan untuk melakukan suatu tindakan. Dan hanya tindakan yang dilakukan dengan tahu-mau-bebaslah, yang bisa disoroti moralnya. 
Jadi, disini jelas terlihat bahwa yang membedakan manusia dengan binatang adalah akal budinya, yang membuat tindakan manusia itu manusiawi adalah akal budinya yang merupakan kapasitas penalaran, sedangkan binatang bertindak hanya karena insting yang dimilikinya.

\section{TATANAN MORAL SUBJEKTIF}

Tatanan Moral Subjektif adalah pedoman moral baik dan buruk yang tertanam dalam diri manusia. "Tatanan moral subjektif memaksudkan dinamisme penilaian baik buruk dari suatu tindakan manusia dipahami pertama-tama sebagai unsur subjek."(Dewantara, 2017: 18). Instansi yang menjadi pengawas tatanan moral subjektif adalah Hati Nurani. "Hati nurani menjadi seperti kapasitas/daya/kekuatan yang pertimbangan dan pemeriksaannya mengatasi hukum, fenomen baik/buruk sebagaimana digagas oleh publik kebanyakan, mengatasi larangan/perintah dalam peraturan-peraturan yang dimiliki oleh tiap hidup manusia." (Dewantara, 2017: 20).

Hati nurani merupakan kapasitas yang dimiliki oleh tiap manusia untuk membedakan mana yang baik dan yang buruk. Sanksi yang berlaku adalah sanksi moral, misalnya rasa bersalah, berdosa, menyesal.

Beberapa macam hati nurani :

a. Hati Nurani Sesat (The erroneous conscience), dapat dikatakan bahwa hati nurani macam ini adalah hati yang ngeyel, hal yang benar (baik) dibalik dianggap salah (buruk) dan hal yang salah (buruk) dibalik dianggap menjadi benar (baik).

b. Hati Nurani Bimbang (Doubtful conscience), hati kita kadang minim pengetahuan sehingga ragu-ragu atau bimbang. "Hati Nurani Bimbang berarti pengetahuannya tidak pasti. Hati nurani tidak pernah bimbang, karena jika bimbang, orang tidak memiliki pengetahuan moralitas dari tindakannya."(A. Dewantara, 2017: 23). Hal yang harus dilakukan untuk mengatasi hati nurani bimbang yaitu memperbaiki hati nurani semacam ini, 
kalau ragu-ragu, keragu-raguannya harus disembuhkan dengan mendapat banyak pengetahuan.

c. Hati Nurani Tumpul (Conscienta laxa), hati semacam ini kurang peka pada nilai-nilai kebenaran sehingga lama-kelamaaan kesetiaannya pada nurani menjadi tumpul. Yang menjadi penyebab ketumpulan yakni materialisme, sekularisme, kosumerisme, hedonisme, dan lain-lain. Manusia kerap menomorsatukan hal-hal tersebut, sehingga pelan-pelan kebenaran dan kesejatian hidupnya tersisih.

d. Hati Nurani Skrupel (Conscienta scrupullosa), mereka yang mempunyai hati seperti ini, merasa bahwa mereka dihantui oleh perasaan untuk tidak berdosa dalam hal yang sekecil-kecilnya dan ingin semua sempurna dan sesuci-sucinya secara ekstrim (skrupel), sebenarnya hal ini patut dipuji, akan tetapi sialnya selalu mengarah pada hal-hal yang objektif dan perfeksionis.

e. Hati Nurani Tajam (hati yang ideal), hati nurani semacam ini terlatih untuk dengan cepat membedakan mana yang baik dan mana yang buruk. Biasanya diperoleh dengan banyak latihan dan pembiasaan yang baik (selayaknya pisau yang sering diasah).

\section{TATANAN MORAL OBJEKTIF}

Tatanan Moral Objektif adalah pedoman moral baik dan buruk di luar manusia. Agustinus W. Dewantara dalam bukunya yang berjudul Filsafat Moral Pergumulan Etis Keseharian Hidup Manusia halaman 30, menerangkan bahwa dalam pembahasan tentang tatanan moral objektif, kita akan menjelajahi tema tatanan moral kita, tatanan moral hidup bersama. Perkara-perkara etis yang diajukan menyentuh penataan hidup bersama. Secara konkret, perkara-perkara itu ialah soal hukum, etika keadilan, dan hak-hak manusiawi. 


\section{HUKUM}

Hukum dalam bahasa Latin "lex". Berasal dari kata "ligare" yang berarti mengikat dan "legere" yang artinya menghimpun, membaca."Hukum adalah itu yang mengikat, namun sekaligus merupakan itu yang kita baca sebagai aneka peraturan yang dihimpun bersama."(Dewantara, 2017: 31). Pengertian hukum (positif) yang digagas oleh Thomas Aquinas, artinya hukum yang diletakkan/diberlakukan dalam masyarakat.

Aquinas menggagas hukum (yang adalah soal perintah dan larangan) sebagai :

i) Ordo rationis atau ordinance of reason (tatanan akal budi). Yang dimaksud dengan akal budi oleh Aquinas, ialah recta ratio atau right reason.

ii) Tatanan akal budi ini dimaksudkan untuk mengejar bonum commune (atau the common good) - kesejahteraan umum.

iii) Sumber dan tatanan akal budi ini berasal dari instansi/pribadi yang bertindak sebagai penanggung jawab atas kesejahteraan umum.

iv) Sebagai hukum tatanan akal budi ini harus dipromulgasikan atau diberlakukan oleh dia yang memegang tanggung jawab suatu pemerintahan. Jika belum dipromulgasikan, hukum hanyalah sebuah draf, rancangan, tulisan yang tidak memiliki daya ikat apa pun. (Dewantara, 2017: 31)

Jika dalam tatanan moral subjektif, hati nurani sebagai instansi pengawas, di dalam tatanan moral objektif misalnya hukum dalam negara, memiliki instansi pengawas seperti polisi, KPK, pengadilan. Pelanggarnya dapat dikenai sanksi berupa hukuman. 


\section{ANALISIS KASUS DEMO BERUJUNG KERUSUHAN 21-22 MEI 2019 YANG DITINJAU DARI TEORI TINDAKAN MANUSIA, TATANAN MORAL SUBJEKTIF, DAN TATANAN MORAL OBJEKTIF}

Berdasarkan kronologi dan fakta-fakta yang terjadi dalam kerusuhan 21-22 Mei 2019 tersebut, ada beberapa poin yang akan dibahas berdasarkan analisis teori tindakan manusia, tatanan moral subjektif, dan tatanan moral objektif.

\section{Analisis Kasus Penembakan Demonstran Ditinjau dari Teori Tindakan Manusia}

Kerusuhan 21-22 Mei 2019 terkait penolakan hasil perhitungan suara Pilpres 2019 banyak menimbulkan kerugian dan juga korban, para demonstran tak hanya mengalami luka-luka, bahkan ditemukan juga demonstran yang tewas sebanyak 9 orang. Dari hasil penyelidikan polisi, 4 dari 9 korban tewas disebabkan oleh luka tembak, yang anehnya selama pengamanan demo, petugas aparat yang berjaga baik Polri maupun TNI tidak dibekali peluru tajam, namun bagaimana bisa terdapat korban tewas karena luka tembak?

Berdasarkan penyelidikan polisi dari hasil uji balistik terhadap proyetil dalam tubuh 2 dari 4 korban tewas luka tembak, menunjukkan arah proyektil yang berlawanan dengan posisi aparat yang berjaga di lokasi ditemukannya korban.

Bahkan ada saksi yang melihat bahwa ada seseorang yang mengarahkan pistol hitam ke arah kerumunan massa saat demo. Dari hal tersebut, polisi menduga bahwa ada seseorang yang dengan sengaja menembak peserta demo.

Berdasarkan kasus tersebut, tindakan penembakan terhadap orang tidak dapat dikatakan dalam tindakan kategori actus hominis, dimana tindakan yang termasuk dalam actus hominis adalah tindakan manusia yang tidak menyertakan peran rasionya dalam bertindak, bertindak hanya berdasarkan insting, refleks dan nampak hanya gerakan yang menunjukkan bertindak sebagai salah satu dari ciri makhluk hidup. Sedangkan tindakan penembakan orang jelas dilakukan dengan menyertakan peran rasio dalam bertindak, sebab tindakan penembakan tersebut pasti sudah direncanakan sebelumnya, mulai dari pistol, lokasi dan sasaran. 
Sehingga tindakan penembakan terhadap orang tersebut dikategorikan ke dalam actus humanus, yakni tindakan manusia yang menyertakan akal budinya, yang dilakukan dengan tahu-mau-bebas, dan sesuai kasus tersebut, pelaku mengetahui tindakan penembakan dan dia secara sadar tahu siapa dirinya dan siapa objek dari tindakannya, dia menghendaki melakukan tindakan penembakan dan serta bebas bertindak untuk melakukan penembakan terhadap salah satu massa demonstran.

Hanya tindakan yang dilakukan dengan tahu-mau-bebas, yang bisa disoroti secara moral, termasuk tindakan menembak orang dalam kasus kerusuhan tersebut. Tindakan tersebut menyimpang dari nilai-nilai kebenaran dan dilakukan dengan pengetahuan, kemauan dan kebebasan., sehingga tindakan penembakan tersebut bisa dikategorikan ke dalam tindakan buruk/ jahat, karena melakukan penembakan terhadap orang tak bersalah hingga tewas, jelas sama halnya tindakan membunuh orang.

Manusia bergerak dan bertindak merupakan hal lumrah yang menunjukkan salah satu ciri dari makhluk hidup. Namun manusia diberikan anugerah berupa akal budi oleh Tuhan yang mana hal tersebutlah yang membedakan manusia dengan makhluk hidup lain. Sudah disebutkan sebelumnya bahwa tindakan penembakan terhadap orang dalam kasus kerusuhan 21-22 Mei 2019 tersebut, bisa disorot secara moral dan termasuk dalam tindakan yang buruk atau jahat, sehingga manusia yang berakal budi dengan anugerah kapasitas penalaran tersebut seharusnya tidak melakukan tindakan tersebut, karena akal budilah yang membuat manusia itu manusiawi.

\section{Analisis Kasus Massa Terorganisir Ditinjau dari Teori Tatanan Moral Subjektif (Hati Nurani Perusuh)}

Dalam kasus demo pasca pilpres 2019, kita ketahui bahwa memang tak berjalan damai dan berujung pada kerusuhan di banyak tempat di Ibu Kota Jakarta. Banyak terjadi penjarahan, kerusakan fasilitas umum, tindakan anarkis yang terjadi pada malam hingga dini hari. Dugaan polisi bahwa ada massa yang terorganisir untuk melakukan kerusuhan dan kekacauan serta provokasi dengan memanfaatkan momentum demo penolakan hasil pilpres 2019. Hal itu dibuktikan 
dengan kedatangan sekelompok orang dengan pergerakan yang sudah seperti terencana, rapi dan masif. Bukti lain, ditemukan amplop berisi uang sekitar Rp 6 juta dari para provokator yang ditangkap polisi, mereka mengaku dibayar untuk melakukan aksi rusuh dan anarkis tersebut. Bukti itu, diperkuat dengan rekaman CCTV yang memperlihatkan sekelompok orang turun dari ambulans dan kemudian pembagian amplop sebelum mereka bubar untuk melakukan aksinya.

Bagaimana dengan hati nurani massa bayaran tersebut? Mengapa mereka tega merusak, membakar mobil dan bahkan melempari petugas dengan barang-barang berbahaya ? Berdasarkan kasus tersebut, hati nurani massa perusuh bayaran tersebut termasuk dalam golongan hati nurani yang tumpul (conscientia laxa), dimana hati semacam ini kurang peka pada nilai-nilai kebenaran, sehingga lamakelamaaan kesetiaannya pada nurani menjadi tumpul. Dalam konteks kerusuhan tersebut, massa bayaran kurang peka pada nilai-nilai kebenaran, bahwa tindakan anarkis, merusak, membuat kerusuhan, menimbulkan kekacauan, merugikan orang lain merupakan tindakan yang buruk dan tidak dibenarkan.

Apa yang menjadi penyebab ketumpulan hati nurani ? Materialisme, sekularisme, kosumerisme, hedonisme dan lain-lain. Seperti halnya kasus tersebut, massa terorganisir tersebut mendapat bayaran sekitar Rp 6 juta untuk melakukan kerusuhan dan membuat kerusakan, sehingga imbalan materi berupa uanglah yang membuat mereka hingga lupa dan kurang peka pada nilai-nilai kebenaran. Mereka dibutakan oleh uang yang membuat mereka berani melakukan tindakan buruk yang merugikan orang lain, tanpa memperdulikan akibat yang timbulkan dan nasib orang lain. Manusia kerap menomorsatukan hal-hal tersebut, sehingga pelan-pelan kebenaran dan kesejatian hidupnya tersisih. "Manusia sejauh manusia memiliki akal budi sehat, artinya memiliki segala apa yang perlu untuk berpikir dan menghendaki yang benar bagi dirinya (kesadaran bahwa dirinya adalah makhluk Tuhan) dan bagi sesamanya yang lain (kesadaran akan kodrat sosialitasnya).(Dewantara, 2017: 31). Sehingga, sebagai makhluk Tuhan, manusia seharusnya sadar bahwa perbuatan-perbuatan merugikan orang lain seperti kerusuhan tersebut termasuk ke dalam golongan dosa, sehingga harus dihindari. Manusia sebagai makhluk sosial, harusnya memahami bahwa ia tidak 
bisa hidup sendiri, menyadari bahwa ia juga hidup bersama orang lain, sehingga perbuatan mengusik, dan bertindak yang merugikan orang lain seharusnya tidak dilakukan. Hal itulah yang harus ditanamkan dalam hati nurani kita, agar terbiasa berpikir dan bertindak sesuai dengan akal budi secara jernih, sehingga dapat mempertajam hati nurani dan tidak kehilangan kesejatian hidup.

\section{Analisis Kasus Demo Yang Berujung Kerusuhan Pasca Pengumuman Hasil Pilpres 2019 Ditinjau dari Teori Tatanan Moral Objektif.}

Negara Indonesia merupakan negara yang menjamin kebebasan menyampaikan pendapat di muka umum bagi warga negaranya, yang tercantum dalam Undang-Undang RI Nomor 9 Tahun 1998 tentang Kemerdekaan Menyampaikan Pendapat di Muka Umum. Dalam Bab I Ketentuan Umum, pasal 1, yang dimaksud dengan demo atau unjuk rasa adalah kegiatan yang dilakukan oleh seorang atau lebih untuk mengeluarkan pikiran dengan lisan, tulisan dan sebagainya secara demonstratif di muka umum. Di dalam undang-undang tersebut telah diatur lengkap mulai dari ketentuan umum, hak dan kewajiban, bentuk dan tata cara penyampaian pendapat di muka umum dan lain-lain, termasuk yang terkait dengan demo atau unjuk rasa. Sehingga jelas bahwa demo tidak asal sembarangan dilakukan, semuanya sudah ada hukum yang mengatur perihal tersebut.

Di dalam Bab IV, UU RI No. 9 Tahun 1998, Bentuk-Bentuk dan Tata Cara Penyampaian Pendapat di Muka Umum, pasal 9 ayat (3) dijelaskan bahwa pelaku atau peserta penyampaian pendapat di muka umum sebagaimana dimaksud dalam ayat (1) (unjuk rasa/demonstrasi, pawai, rapat umum, dan atau mimbar bebas) dilarang membawa benda-benda yang dapat membahayakan keselamatan umum.

Namun bagaimana pelaksanaan undang-undang tersebut oleh warga negara dalam demo pasca Pilpres 2019 ? terlihat sungguh memprihatinkan karena berujung pada kerusuhan. Bagaimana bisa dikatakan memprihatinkan ? kenyataannya apa yang telah diatur dalam UU tersebut tidak diperhatikan dan bahkan diabaikan oleh para warga yang melakukan demo tanggal 21-22 Mei 2019. Mereka melakukan demo dengan membawa alat-alat, senjata dan barang-barang 
yang sangat berbahaya, seperti bom molotov, petasan, batu. Dan bahkan parahnya, ketika diprovokasi dan memicu keributan, barang-barang tersebut dilempar kepada aparat yang berjaga saat demo.

Selain itu, dalam Bab III UU No. 9 Tahun 1998, yang mengenai Hak Dan Kewajiban, pasal 6 salah satunya dijelaskan bahwa warga negara yang menyampaikan pendapat di muka umum wajib dan bertanggung jawab untuk menjaga dan menghormati keamanan dan ketertiban umum, akan tetapi pada Rabu dini hari 22 Mei 2019, tak disangka-sangka bahwa ada massa yang datang, dan berbuat kerusuhan, kekacauan di asrama Brimob. Padahal dalam asrama tersebut, terdapat anak dan istri anggota polri, bagaimana jika terjadi hal-hal yang bisa membahayakan keluarga anggota polri yang tidak bersalah tersebut.

Berdasarkan kejadian-kejadian tersebut, demo tanggal 21-22 Mei 2019 jelas melanggar hukum di Indonesia. Dan apa yang dilakukan oleh para demonstran rusuh tersebut jelas membahayakan dan mengganggu ketertiban, merugikan berbagai pihak, memicu kebencian, dan perpecahan bangsa. Mereka mengabaikan peraturan yang telah ada dan bertindak bertentangan dengan tatanan moral objektif yakni hukum yang berlaku di Indonesia, khususnya terkait demo.

Kemerdekaan mengungkapkan pendapat adalah hak manusia, dan negara Indonesia telah menjamin kesempatan dan kebebasan kepada semua warga negaranya, melalui peraturan hukum yang telah dibuat. Hukum dibuat bertujuan agar terciptanya kesejahteraan umum. Hukum yang baik memerintahkan pada kebaikan dan melarang pada keburukan.

Demikian pula UU No. 9 Tahun 1998 tentang Kemerdekaan Menyampaikan Pendapat di Muka Umum, undang-undang tersebut telah dibuat, disusun, dan disahkan sedemikian rupa sehingga agar pelaksanaan bentuk-bentuk kemerdekaan menyampaikan pendapat seseorang terjamin dan terlaksana dengan tetap memperhatikan kepentingan umum, agar terlaksananya ketertiban bersama.

Sebagai makhluk sosial, manusia tidak bisa hidup sendiri, dan dalam hidup bersama dalam suatu negara seperti Indonesia, terdapat hukum yang mengatur hidup bersama dan telah disepakati, salah satunya mengatur tentang demo. 
"Hukum itu soal akal budi, daya ikat/wajib hukum didasarkan pada kebenaran sejauh akal budi manusia dapat memikirkannya."(Dewantara, 2017: 31). Demo dilarang membawa peralatan yang berbahaya, hal itu jelas benar, karena yang ditakutkan akan timbul tindakan-tindakan yang dapat mencelakakan orang lain.

Selain itu, aksi unjuk rasa atau demo harus dijalankan dengan tetap bertanggung jawab pada keamanan, ketertiban dan persatuan bangsa, dimaksudkan agar pelaksanaan demo berjalan damai, tertib, tidak merugikan orang lain, dan tidak mengganggu kepentingan umum serta menghindari terjadinya kerusuhan yang mengancam keutuhan bangsa. Dalam peraturanperaturan terkait pelaksanaan demo diatas, kita ketahui bahwa isi dalam peraturan tersebut benar dan logis. Sehingga jelas memiliki daya ikat dan wajib dilaksanakan oleh semua warga negara yang ingin melakukan demo atau unjuk rasa. 


\section{E. KESIMPULAN}

Berdasarkan peristiwa demo yang berujung pada kerusuhan tanggal 21-22 Mei 2019 pasca pengumuman hasil Pilpres 2019, dapat kita ambil pelajaran bahwa kita sebagai manusia seharusnya memahami sejauh manusia secara mendalam, tak hanya sekedar menyadari diri pribadi sebagai makhluk Tuhan namun juga kehidupan bersama sesamanya, misalnya dalam kehidupan bernegara seperti kegiatan demo atau unjuk rasa. Kesadaran kita akan di dalam kehidupan bernegara dengan adanya hukum yang telah ada, demo tak seharusnya dilakukan dengan kerusuhan dan menimbulkan kerugian bagi orang lain. Kerugian harta, korban jiwa, dan bahkan mengancam persatuan Negara Republik Indonesia. Hal itulah yang harus menjadi pertimbangan hati nurani kita, jangan hanya karena materialisme, hedonisme semata, kita buta akan eksistensi manusia yang sebenarnya. 


\section{F. DAFTAR PUSTAKA}

Dewantara, AW. 2017. Filsafat Moral Pergumulan Etis Keseharian Hidup Manusia. Yogyakarta: PT Kanisius.

https://amp.kompas.com/nasional/read/2019/05/23/09121101/perusuh-22-meidari-by-design-massa-bayaran-hingga-dalang-kerusuhan. (Diakses pada tanggal 11 November 2019)

https://amp.kompas.com/nasional/read/2019/06/11/20190081/polri-9-korbanmeninggal-dunia-rusuh-21-22-mei-2019-kami-duga-perusuh. (Diakses pada tanggal 14 November 2019) https://amp.kompas.com/nasional/read/2019/07/05/15155581/polisi-2-korbantewas-pada-kerusuhan-22-mei-diduga-ditembak-orang-tak. (Diakses pada tanggal 13 November 2019)

https://id.wikipedia.org/wiki/Pemilihan_umum_legislatif_Indonesia_2019.

(Diakses pada tanggal 6 November 2019)

https://m.liputan6.com/news/read/3971668/hasil-resmi-rekapitulasi-kpu-pilprea-

2019. (Diakses pada tanggal 28 November 2019)

https://m.liputan6.com/news/read/3974024/penjarahan-dan-kerusakan-usai-aksi22-mei-di-kawasan-bawaslu. (Diakses pada tanggal 15 November 2019)

https://www.tempo.co/abc/4383/polisi-ungkap-dua-korban-tewas-kerusuhan-21-

22-mei-2019-ditembak-orang-tidak-dikenal. (Diakses pada tanggal 13

November 2019)

https://m.tribunnews.com/amp/nasional/2019/05/27/rekaman-cctv-ungkap-asal-

perusuh-aksi-22-mei-ada-yang-turun-dari-kerta-dan-ambulans-dapat-

amplop?page $=2$. (Diakses pada tanggal 14 November 2019) 
https://m.tribunnews.com/amp/nasional/2019/05/27/rekaman-cctv-ungkap-asal-

perusuh-aksi-22-mei-ada-yang-turun-dari-kerta-dan-ambulans-dapat-

amplop?page=3. (Diakses pada tanggal 14 November 2019)

https://m.tribunnews.com/amp/pilpres-2019/2019/05/21/resmi-pengumuman-kpu-

hasil-pilpres-2019-selisih-suara-jokowi-maruf-vs-prabowo-sandi-16-juta-

lebih (Diakses pada tanggal 6 November 2019)

https://www.bbc.com/indonesia/indonesia-48345791. (Diakses pada tanggal 13

November 2019)

https://www.matamatapolitik.com/in-depth-fakta-kerusuhan-22-mei-kronologi-

korban-hingga-tersangka-perusuh. (Diakses pada tanggal 6 November 2019)

https://www.suara.com/news/2019/05/22/100725/jakarta-kerusuhan-22-mei-

korban-luka-tembus-200-orang. (Diakses pada tanggal 14 November 2019)

Undang-Undang RI No. 9 Tahun 1998 tentang Kemerdekaan Menyampaikan

Pendapat di Muka Umum diunduh melalui

https://radenfatah.ac.id/tampung/hukum/20161123113545uu-

09_1998_tth_kemerdekaan-menyampaikan-pendapat-di-muka-umum.pdf.

(Diakses pada tanggal 17 November 2019)

Dewantara, A. (2019). POLITIK MENURUT FOUCAULT DALAM “THE

ARCHAEOLOGY OF KNOWLEDGE” DAN RELEVANSINYA BAGI

MULTIKULTURALISME INDONESIA.

Dewantara, A. (2018). Alangkah Hebatnya Negara Gotong Royong (indonesia

Dalam Kacamata Soekarno).

Dewantara, A. W. (2013). Merefleksikan Hubungan antara Etika Aristotelian dan

Bisnis dengan Studi Kasus Lumpur Lapindo. Arete, 2(1), 23-40.

Dewantara, A. W. (2017). Kerasulan Awam Di Bidang Politik (Sosial-

Kemasyarakatan), Dan Relevansinya Bagi Multikulturalisme

Indonesia. JPAK: Jurnal Pendidikan Agama Katolik, 18(9), 3-15.

Dewantara, A. (2017). Filsafat Moral (Pergumulan Etis Keseharian Hidup

Manusia). 